\title{
Lexical Chunks and Translation
}

\author{
Fangrong Liu \\ School of Foreign Languages \\ Wuhan Textile University \\ Wuhan, P. R, China \\ E-mail: 178146790@qq.com
}

\begin{abstract}
The previous researches mainly highlight the influences of lexical chunks upon English listening, reading and writing, never involving the relationship between lexical chunks and translation. To make it clear, through the analysis of the definition and classification of lexical chunks, the thesis throws light on the nature of translation from the prospective of linguistics, so that the nature of translation texts can be clarified. Meanwhile, it provides a brand-new perspective for the research of translation.
\end{abstract}

Keywords-lexical chunks; definition; classification; translation

\section{INTRODUCTION}

Lexical chunks are groups of vocabulary between grammar and vocabulary, with independent meanings or functions and are used at the same time. "They are the smallest units of human language communication, and form the basis of languages."'[1] But the translation is considered to be the concrete language not the transformation between the language systems, "changing the product of a kind of verbal language, while maintaining the content or meaning unchanged, into another language products"[2]; "and recur the information of the original language by using the nearest natural equivalents from the semantic meaning to the style"[3]. Generally speaking, translation is "from one language to another language" or "the transformation from one utterance to another equivalent language". Most human language communication succeeds by means of lexical chunks not by word forms. Winddowson (1989) points out, "learning chunks is more important than grammatical learning. Moreover, the mastery of substantial chunks can help learners reach the native speakers in the choice of words"[4]. Therefore, the paper is going to explore the functions of chunks in the translating course depending on the definition and classification, to explain the nature of the translation of texts.

\section{THE DEFINITION OF LEXICAL CHUNKS}

Linguistic field has given different terms for lexical chunks and received different kinds of research findings, among which the most common ones are "prefabricated chunk", "form-meaning pairings", "chunks", "lexical bundles", etc. Becker, the earliest to notice and begin to do some research on chunks, found that the smallest unit of human language communication was not the single words, but the patterned language plates with specific meanings, with fixed or semi-fixed structure. In the 1970s, Becker (1975) \& Bolinger (1975) were the first to raise the concept of "prefabricated chunk"[5]. Pawley \& Syder (1983) defined this phenomenon "lexicalized sentence stems"[6]. They thought that people should first master those lexicalized sentence parts to master the language. Moon(2002) gave a broader idea. He described the phenomenon by using "multiword items", saying "the word groups with two or more words are complete and inseparable in the forms of semantic meaning and grammar"[7]. For this language phenomenon, Nattinger \& Decarrico (2000) had done a lot more research work. In their eyes, those changeable and formulated language is the inexhaustible source of the language development, which they gave the name "lexical phrases"[8].

Among the above definitions about lexical chunks, the one given by Nattinger \& Decarrico has been used in the following research.

\section{THE ClASSIFICATION OF LEXICAL CHUNKS}

Lewis, Nattinger \& DeCarrico have given their own classifications for lexical chunks, which are very influential in the history.

\section{A. The Classification by Lewis}

Early in 1993, Lewis coined the term lexical approach, which suggests the following points:

1) Lexis is the basis of language.

2) Lexis is misunderstood in language teaching because of the assumption that grammar is the basis of language and that mastery of the grammatical system is a prerequisite for effective communication.

3) The key principle of a lexical approach is that "language consists of grammaticalized lexis, not lexicalized grammar." [9]

4) One of the central organizing principles of any meaning-centered syllabus should be lexis.

Then Lewis (1997b) suggests the following taxonomy of lexical items:

- $\quad$ words (e.g., book, pen)

- polywords (e.g., by the way, upside down) 
- collocations, or word partnerships (e.g., community service, absolutely convinced)

- institutionalized utterances (e.g., I'll get it; We'll see; That'll do; If I were you ...; Would you like a cup of coffee?)

- sentence frames and heads (e.g., That is not as...as you think; The fact/suggestion/problem/danger was ...) and even text frames (e.g., In this paper we explore ...; Firstly ...; Secondly ...; Finally ...) [10]

\section{B. The classification by Nattinger \& DeCarrico}

\section{1) Polywords}

Polywords don't allow any change in the form. They are serial, standard or nonstandard. They have the functions of words, although they look like phrases. Their functions involve judging, connecting, transforming and summarizing the topics. These words are like as a whole, in a word, etc.

\section{2) Conventionalized or institutionalized expression}

Most of conventionalized or institutionalized expressions are proverbs, sayings and formulated communicative language, which are independent utterances and units of sentences. Most of them are standard and continual phrases with unchangeable forms, such as Nice to meet you, Seeing is believing, etc..

\section{3) Phrasal constraints}

These phrasal phrases are standard and nonstandard, allowing the change of cases. Most of them are made up of continual words, like a couple of, see you soon later, etc..

\section{4) Sentence builders}

Such type of chunks usually provide frames for sentences with some blanks. Those are standard or nonstandard, with a lot of free changes, which are continual or not continual, such as it is impossible for ... to do ..., my points is that ..., etc..

The paper adopts the classification made by Nattinger $\&$ DeCarrico to analyze the chunks in the following research.

\section{ThE Application OF LeXiCAL CHUNKS IN THE TRANSLATION}

Many linguists have done some researches on the translation from different angles, which include literature and art, linguistics, communicative approach, social semiotics and translation science. The angle of literature and art involves the research into the translation and problems with the translating process by means of the theory of literature and art, and providing the literature and art theory on translation. It focuses on the result of translation research, especially on the research and comparison on the differences of the main structures, the styles and artistic effects. Linguistic methodology puts its emphasis on the comparison between the language elements of the original text and its translation, focusing on the grammatical correspondence and vocabulary correspondence. Communicative method involves the comparison on the communicative functions of the language in the original text and its translation by means of the communicative theory and information theory. Social semiotics treats the translation problems from the perspective of sociology and semiotics, laying the emphasis on the research and comparison on the meanings of specific signs on some specific social occasions in the corresponding translations. Translation science distinguishes the translation and translating research, claiming that translation itself is not a science, but a kind of skill or art. The paper is to study the translation from the angle of linguistics because the focus of the paper is on the relationship between lexical chunks and translation.

The primary aim of linguistics is to study "how to seek the equivalence in different language phenomena". Linguistics studies not only the grammar, but also words, phrases, sentences and discourses, which are the translating units. Lexical chunks are language phenomena with fixed structures in the real language communication, integrating grammar, semantic meanings and language contexts. Many researches showed that lexical chunks accounts for a large part of utterances made by foreign language learners, which directly influence the proficient use of language and learners' native-like language. Therefore, during the process of translation, the original texts and their corresponding translations use the lexical chunks, which proves that lexical chunks are an indispensable part of translation process.

Translation process involves the creative recurrence of the original texts by means of another language based on the correct understanding of the original texts, including three steps: understanding, expressing and checking. Understanding is done on the basis of the contexts of the original texts. The contexts refer to a sentence, or a paragraph, or a passage, or a chapter, or a whole book. Translators must understand the words meanings, sentences structures and idioms of the original texts according to the contexts, thus they can know in a sentence or a paragraph which are polywords, conventionalized or institutionalized expression, phrasal constraints and sentence builders according to the classification of lexical chunks by Nattinger \& DeCarrico. Expressing is that translators express the contents understood in the original texts using the corresponding lexical chunks in their native language. Checking involves the further modification of lexical chunks in the translation work.

The following is a part of a speech made by Premier $\mathrm{Li}$ Keqiang in the luncheon of Chinese and German industrial and commercial circles on May $17^{\text {th }}$ in 2013 and the corresponding English translation on the internet, which will be analyzed from the angle of lexical chunks.

“此访期间, 我同德国领导人进行了友好、坦诚的会 谈, 与默克尔总理在一起的时间就有 7 个小时, 就深化 中德战略伙伴关系达成新的共识, 成果十分丰富。我还 与德国企业家进行了对话交流。中德双方不仅将继续落 实两国政府碰商机制和总理年度会晤机制, 还将推动中 德几十个务实合作机制深入开展工作。刚才, 我会见了 中德经济顾问委员会的代表。这一委员会由双方具有丰 富资源和强大实力的金融、实业企业负责人担任主席和 副主席。委员会的成立表明, 不仅两国政府高度重视深 
化双边经贸关系, 两国经济界还开辟了新的战场。这是 中国同欧盟国家、世界主要经济体建立的首个经济顾问 委员会, 成为中德经贸合作的 “第二轨道”。火车跑得 快, 离不开两条轨道这个基础。政府、企业全面加强合 作, 可以使‘两条轨道”一起发挥作用, ‘两个轮子’一起 转。总之, 中德关系发展具有强大的混合动力, 已全面 进入快车道和提速期。”[11]

"During my visit, I have had cordial and friendly meetings with German leaders. I had meeting lasting seven hours with Chancellor Merkel and we reached new agreement on boosting China-Germany strategic partnership. I also had a dialogue with German business leaders. China and Germany will continue governmental consultation and annual meeting between heads of government, and make more progress in several dozen mechanisms on cooperation. I have just met with representatives of the China Advisory Council, whose chairman and vice chairmen are heads of well-established and influential financial and industrial corporations of both countries. The founding of this Council not only shows the importance both governments attach to bilateral business relations, but also opens a new channel for conducting business cooperation. This is the first council of its kind set up between China and Germany, an EU country and a major global economy, and it has become a second track for boosting China-Germany business relations. A train can only run fast on two tracks. When governments and businesses work together, both tracks will be able to play their roles and both wheels will turn. In short, ChinaGermany relations, driven by a powerful hybrid engine, are speeding up along the fast track." [11]

In the original speech, Premier Li Keqiang used some typical Chinese lexical chunks, like “中德战略伙伴关 系”、“继续落实两国政府磋商机制和总理年度会晤机 制”、“双边经贸关系”、“中德经贸合作的“第二轨道”、 “快车道和提速期”. The corresponding lexical chunks of those Chinese lexical chunks in the English translation are "China-Germany strategic partnership", "governmental consultation and annual meeting between heads of government", "bilateral business relations", "a second track for boosting China-Germany business relations" and "speeding up along the fast track". According to the classification of lexical chunks by Nattinger \& DeCarrico, the lexical chunks in the above English translation fall into the following categories: "Table. I"

TABLE I. THE LEXICAL CHUNKS IN THE ABOVE ENGLISH TRANSLATION FALL

\begin{tabular}{|c|c|c|c|}
\hline Polywords & $\begin{array}{c}\text { Conventionalized or } \\
\text { institutionalized expressions }\end{array}$ & Phrasal constraints & Sentence builders \\
\hline $\begin{array}{l}\text { on cooperation; } \\
\text { In short; along } \\
\text { the fast track; }\end{array}$ & & $\begin{array}{l}\text { During my visit; reached new agreement on; } \\
\text { boosting China-Germany strategic partnership; } \\
\text { continue governmental consultation and annual } \\
\text { meeting; make more progress; met with; attach } \\
\text { importance to...; opens a new channel for; set up; } \\
\text { work together; speeding up. }\end{array}$ & $\begin{array}{l}\text { had cordial and friendly meetings with...; } \\
\text { had a dialogue with...; whose chairman } \\
\text { and vice chairmen are...; not only..., but } \\
\text { also...; When...; }\end{array}$ \\
\hline
\end{tabular}

As is shown in the above table, phrasal constraints are used among the highest frequency in the translation process, followed by sentence builders, polywords, and conventionalized or institutionalized expressions. This is because phrases are the smallest units of a sentence, i.e. phrasal constraints, and because the sentence translation can not be done without the fixed sentence structures, i.e. sentence builders. Therefore, phrasal constraints and sentence builders are used most frequently in the translation. Conventionalized or institutionalized expressions are usually used in some certain contexts because of their fixed meanings and thus are used relatively less in the translation.

\section{CONCLUSION}

Translation and lexical chunks are closely related. Lexical chunks can facilitate the development of translation while translation can help to increase the number of lexical chunks. During the course of translation, the full understanding, analysis, acquisition and application of lexical chunks can make translation work more meaningful and fruitful.

\section{REFERENCES}

[1] Lewis, M. The Lexical Approach[M]. Hove, England: Language Teaching Production, 1993: 73-95.

[2] Barkhudarov. Language and Translation $[\mathrm{M}]$, China Translation and Publishing Corporation. 1985.

[3] Nida, Eugene A. And Charles Taber. The Theory and Practice of Translation. Leiden: E. J. Brill. 1969.

[4] Winddowson, H. G. Knowledge of Language and Ability for Use [J].Applied Linguistics, 1989,(5):86-96.

[5] Becker, J. The Phrasal Lexicon[M]. Cambridge: Bolt, Beranek and Newman, 1975. Bolinger, D. Aspects of Language[M]. New York: Barcout Brace Jovanovich, 1975.

[6] Pawley, A. \&F. Syder. Two Puzzles for Linguistic Theory: Native-like Selection and Native-like Fluency[A]. In J.Richards\&R. Schmidt (eds.).Language and Communication[C]. New York: Longman, 1983.101-121.

[7] Moon, R. Vocabulary Connections: Multi-word Items in English[A]. In N. Schmitt\&M. McCarthy (eds.).Vocabulary: Description, Acquisition and Pedagogy[C]. Shanghai: Foreign Language Education Press, 2002.31-33.

[8] Nattinger, J. \&J. DeCarrico. Lexical Phrases and Language Teaching $[\mathrm{M}]$. Shanghai: Shanghai Foreign Language Education Press, 2000.

[9] Lewis M. Implementing the Lexical Approach[M].Hove, England: Language Teaching Publications , 1997.212.

[10] Lewis, M. (1993). The lexical approach: The state of ELT and the way forward $[\mathrm{M}]$. Hove, England: Language Teaching Publications.

[11] http://learning.sohu.com/20130715/n381611958.shtml 